Dicle Üniversitesi Veteriner Fakültesi Dergisi
https://dergipark.org.tr/tr/pub/duvetfd
Derleme/Review
$\begin{gathered}\text { Dicle Üniv Vet Fak Derg 2021;14(1):77-82 } \\ \text { DOI: 10.47027/duvetfd.827886 }\end{gathered}$

\title{
Viruslarda Genetik Değişiklere Bağlı Konakçı Değişimleri
}

\author{
Selin Nur KIZILKOCA ${ }^{1, a, \bowtie}$, B. Taylan KOÇ⿻, \\ ${ }^{1}$ Aydın Adnan Menderes Üniversitesi, Veteriner Fakültesi, Viroloji Anabilim Dalı, Aydın, TÜRKiYE \\ aORCID: 0000-0002-8766-6379; ' ${ }^{\mathrm{O} O R C I D: ~ 0000-0002-4279-6233 ; ~ ' O R C I D: ~ 0000-0001-5253-4010 ~}$
}

\begin{tabular}{ccc}
\hline Geliş Tarihi/Received & Kabul Tarihi/Accepted & Yayın Tarihi/Published \\
18.11 .2020 & 25.01 .2021 & 30.06 .2021 \\
\hline
\end{tabular}

Öz

Viruslar ekolojide en dinamik mikro varlıklardır. Yapısı ve replikasyon stratejileri itibarıyla doğada varlıklarını sürdürmek için bir konakçıya ihtiyaç duyarlar. Viruslar genellikle replikasyon sırasında konakçısında olumsuz durumlar meydana getirirler. Virusun yapısına katacağı konakçı hücresinde sentezlenen proteinler konakçı hücre için hastalık tetikleyici unsurlar olmaktadırlar. Ekolojide değişen dengeler ve koşullar konakçı-virus ilişkisi üzerinde de sürekli bir değişime yol açmaktadır. Özellikle genomik yapıda meydana gelen değişimler virusların konakçı affinitesini de etkilemektedir. Virus genomunda meydana gelen bu değişikler ekolojide yer alan en gelişmiş canlılar olan insanların ve hayvanların sağıı̆ı için büyük önem taşırlar. Buna en güncel örneklerden biri Coronavirus Disease-19 (COVID-19) salgını ve etkeni olan Severe Acute Respiratory Syndrome-Coronavirus-2 (SARS-CoV-2)'dir. SARS-CoV-2 orijin olarak nereden veya hangi canlıdan köken aldığı kesin olarak bilinmese de yapılan genetik analizler sonucu bazı yarasa ve pangolin türlerinde bulunan coronaviruslara yakınlık gösterdiği ortaya konmuştur. Bu sonuç SARS-CoV-2'nin mutasyonlar sonucu konakçı değiştirme ihtimali yüksek olan bir virus olabileceği hipotezini güçlendirmektedir. Bu kapsamda, derlemede, zaman içerisinde genetik farklılık geçirdikten sonra konakçı affinitesi değişen viruslardan bahsedilmiştir. Ayrıca geçmiş dönemde meydana gelen bu değişiklikler göz önünde bulundurularak gelecekte meydana gelebilecek yeni konakçı değişimleri ve muhtemel hastalık salgınları hakkında da öngörüler derlememizde konu edilmiştir.

Anahtar Kelimeler: CoV, CPV, HIV, konakçı değişimi, mutasyon

Host Shifts Related to Genetic Changes in Viruses

\section{Abstract}

Viruses are the most dynamic micro beings in ecology. In terms of their structure and replication strategies, they need a host to survive in nature. This circumstance that viruses have performed in the host to survive usually creates unfavorable conditions. The proteins that the virus get to its structure and synthesized in the host cell are disease triggering factors for the host cell. Altering balances and conditions in ecology cause a continuous change in the host-virus relationship. In particular, changes in the genomic structure affect the host affinity of the viruses. These changes occurring in the virus genome are of great importance for the most developed living things in ecology, that is, human and animal health. One of the most recent examples of this is the Coronavirus Disease-19 (COVID-19) outbreak and its agent, Severe Acute Respiratory Syndrome-Coronavirus-2 (SARS-CoV-2). Although it is not exactly known where or from which creature the SARS-CoV-2 originated, genetic analyzes revealed that it was close to coronaviruses found in some bat and pangolin species. This result strengthens the hypothesis that SARS-CoV-2 may be a virus with a high probability of changing the host as a result of mutations. In this context, in the review, viruses whose host affinity changed after a genetic difference was mentioned over time. In addition, considering these changes that occurred in the past, new host changes that may occur in the future and predictions about possible disease outbreaks are also included in our current review.

Key Words: CoV, CPV, HIV, host shift, mutation

\section{Giriş}

Viruslar genetik materyal olarak DNA veya RNA'dan oluşan tek bir nükleik asit çeşidi taşımaktadırlar. Virusların çoğalması viral nükleik asitin replikasyonuna dayanır ve çoğalma stratejileri viral nükleik asitin çeşidine bağlı olarak değişiklikler gösterir (1). Virusların genetik materyallerinde birçok nedenle değişiklik ve farklılaşmalar meydana gelir. Genetik şifrenin değişimiyle sonuçlanan, nükleik asit baz dizininde kalıcı değişikliklere yol açan, genotipte kalıtsal olarak sentezlenecek proteinin yapısını ve işlevini değiştirme olayına mutasyon denir (2). Virusların doğada varlığını sürdürme yollarından en önemlisi mutasyon geçirebilme yetenekleridir. Viruslarda mutasyonun birçok sebebi vardır. Ancak mutasyonlar sıklıkla replikasyon aşamasında meydana gelir. DNA virusları ile RNA viruslarının mutasyon oranı kıyaslandığında, RNA viruslarında mutasyon görülme oranı çok daha yüksektir (3). DNA viruslarında mutasyonlara daha az rastlanmasının sebebi, DNA polimerazın barındırdı̆̆ı eksonükleaz aktivitesine bağlı proofreading mekanizmasıyla ilgilidir. RNA viruslarının tek iplikçikli olmasına karşın DNA viruslarının çift iplikçikli sayesinde gen kodlamalarında herhangi bir hatayı tamamlayarak kendilerini düzeltme imkânı vardır (4). 
Mutasyonlar hastalık epidemiyolojisini etkilemektedir. Endemik seyirli bir enfeksiyon mutasyonlara bağlı olarak pandemik bir enfeksiyona dönüşebilir (5). Virusların mutasyon geçirmesi, virusun antiviral ilaçlara karşı direnç geliştirmesine neden olmaktadır (6).

Viruslarda mutasyonların bir diğer nedeni mutajenlerdir. Mutasyon oluşumuna neden olan fiziksel ve kimyasal faktörlere mutajen denir (1). Mutajenler, fiziksel mutajenler ve kimyasal mutajenler olmak üzere ikiye ayrılır. Kimyasal mutajenler; baz analogları, nükleotid bazları değiştiren ajanlar, alkilleyici ajanlar, asilleyici ajanlar, interkalasyon yapan ajanlar olarak sıralanabilir. En yaygın olarak karşılaşılan kimyasal mutajenler arasında baz analogları ve nitröz asiti önemli yer tutar (7). Isı ve $\mathrm{pH}$, iyonize ışın, non-iyonize ışın (UV ışın) genel anlamda fiziksel mutajenlerdir. Ultraviyole ve $\mathrm{X}$ ışınları fiziksel mutajenlerden en yaygın olanlardır (8).

Virus konakçı bağlanmasını kontrol eden veya etkileyen birçok faktörün tanımlanmasında önemli ilerlemeler kaydedilmiştir. Yeni virusların kökenleri hakkında daha çok bilgi edinildiği takdirde, doğal konakçılarında potansiyel olarak ortaya çıkan virusları tespit etmek ve kontrol etmenin mümkün olabileceği bildirilmiştir (9).

\section{Mutasyon Sonucu Konakçı Değiştiren Viruslar}

Virusların bir konakçı türünden diğerine türler arası geçişi, ortaya çıkan enfeksiyonların çoğundan sorumludur. Genel olarak, türler arası bulaşmanın virus evriminde önemli bir rol oynadığını, bazı incelenen virus ailelerinin konakçı türleri değiştirme potansiyeline sahip olduğu belirtilmiştir (10). Ortaya çıkan bulaşıcı hastalıklar genellikle, bir patojenin orijinal konağından atlayarak yeni bir türü enfekte etmek için konakçı değiştirme olayları ile karakterizedir (Tablo.1). Bununla birlikte, bir virusun konakçı değiştirmesi ve yeni konakçılara adapte olması için ekolojik ve genetik durumlar etkilidir. Çapraz konakçı değişimi virus mutasyonunda temel rol oynar (1). Geniş karşılaştırmalar yapılarak, hangi virus ailelerinin konakçı bariyerlerini atlama eğiliminde olduğu tespit edilmiş ve yeni konakçılarda başarılı bir şekilde adaptasyon meydana geldiği ortaya konmuştur (11). Türler arası geçiş sıklıklarının belirlenmesi, virus evrimi ve hastalıkların ortaya çıkmasının temel mekanizmalarını anlamak için çok önemlidir. Özellikle, bazı virus ailelerinin konakçılara diğerlerinden daha fazla geçme eğilimi olup olmadığını ve bu durumu hangi faktörlerin etkilediğini belirlemek önemlidir (9). Bununla birlikte, çapraz türlere karşı çapraz tür değişim sıklığının kantitatif veya karşılaştırmalı bir ölçüsü yoktur. Bundan dolayı bir virus ailesinin tür sınırlarını bir diğerinden daha fazla atlama olasılığının, daha yüksek olup olmadığını belirlemek zordur. Bu temel evrimsel parametreleri tahmin etmenin basit ve etkili yolu, konakçılar ve viruslar arasındaki filogenetik uyum yani benzerlik derecesini değerlendiren filogenetik analizlerdir (12). Filogenetik olarak ilişkili konakçılar arasında başarılı çapraz konakçı değişimi daha sık meydana gelir. Çünkü genetik olarak benzer konakçılarda virusun enfekte etmesi ve çoğalması daha kolaydır. Ayrıca, ilgili konakçılar bazen aynı alanda yaşayabilir ve daha çok maruz kalma yoluyla türler arası bulaşma olasıığını arttırabilir (12).

Tablo 1. Mutasyona bağlı çapraz konakçı değişimine uğrayan viruslar

\begin{tabular}{|c|c|c|c|}
\hline Viruslar & Ana konakçı & Yeni konakçı & Konakçı değiştirme mekanizması ve süresi \\
\hline $\begin{array}{l}\text { CPV (Canine } \\
\text { Parvovirus) }\end{array}$ & Kedi & Köpek & $\begin{array}{l}\text { Feline Panleukopeni virusunun mutasyona uğraması ile Canine Parvovirus'un ortaya çıktığı benim- } \\
\text { senmektedir. FPV, köpek transferrin reseptörüne etkili bir şekilde bağlanmasına izin veren, kap- } \\
\text { siddeki en az iki nokta mutasyonu sonucu 1970'lerin başında ortaya çıkıp, 1978'de dünyaya yayıl- } \\
\text { mıştır (9). }\end{array}$ \\
\hline $\begin{array}{l}\text { İnfluenza } \\
\text { virus }\end{array}$ & Su kuşları & $\begin{array}{l}\text { İnsanlar, do- } \\
\text { muzlar, atlar }\end{array}$ & $\begin{array}{l}\text { İnfluenza virusundaki sabit nokta mutasyonlarından kaynaklanan antijenik bölgelerdeki önemli } \\
\text { mutasyonlar, virusun aşamalı evrimine katkıda bulunur ve popülasyonun bağışılık mekanizmasın- } \\
\text { dan kaçmak için yeni İnfluenza virusu alt tipleri üretmek üzere antijen göçüne yol açar. Antijenik } \\
\text { Drift ve antijenik shift (antijenik kayma), nokta mutasyonları sonucunda yeni viruslar oluşur } \\
(33,34)\end{array}$ \\
\hline HIV-1 & $\begin{array}{l}\text { Şempanzeler ve } \\
\text { primatlar }\end{array}$ & İnsanlar & $\begin{array}{l}\text { HIV, Simian İmmunodeficiency Virus (SIV)'dan 1930'lu yılardan sonra zaman içinde evrimleşerek } \\
\text { geliştiği düşünülmektedir. Ters transkriptazın DNA sentezlerken yaptığı hatalar kendi gen dizisinde } \\
\text { mutasyonlar oluşturur. CCR5 genindeki (T hücresi üzerindeki HIV'in bağlandığı koreseptör) } 32 \text { baz } \\
\text { çiftinde delesyon sonucu CCR5 reseptöründe mutasyon bulunmaktadır. Nokta mutasyonları görü- } \\
\text { lür (18-19) }\end{array}$ \\
\hline SARS CoV & Yarasalar & İnsanlar & $\begin{array}{l}\text { İnsanlarda } A_{C} \text { reseptörüne bağlanmak için mutasyonlar geçirmiştir. 2003-2004 yıllarında görül- } \\
\text { müştür (14). }\end{array}$ \\
\hline MERS & Develer & İnsanlar & $\begin{array}{l}\text { MERS-CoV başak glikoproteini (S), hücresel reseptör dipeptidil peptidaz 4'ü (DPP4) hedefler ve } \\
\text { yayılımında mutasyonlar etkili olmuştur (16). }\end{array}$ \\
\hline CoV-2 & Yarasalar & İnsanlar & $\begin{array}{l}\text { SARS Cov-2 izolatlarında yapısal olmayan protein 6'yı (NSP6) ve ORFoto10 bölgelerini etkile- } \\
\text { yen iki mutasyonun varlığı bulunmuştur ve çalışmalar devam etmektedir (17). }\end{array}$ \\
\hline $\begin{array}{l}\text { Kızamık } \\
\text { Virusu (MV) }\end{array}$ & $\begin{array}{l}\text { Muhtemelen Sı- } \\
\text { ğır }\end{array}$ & İnsanlar & $\begin{array}{l}\text { 11. ve 12. yüzyıllar arasında Kızamık virusunun, o zamanlar yaygın olan sığır vebası virusundan } \\
\text { büyük olasılıkla yer değiştirme mutasyonu sonucu gelişmiştir (40). }\end{array}$ \\
\hline $\begin{array}{l}\text { Small } \\
\text { Poxvirus }\end{array}$ & $\begin{array}{l}\text { Develer ve pri- } \\
\text { matlar }\end{array}$ & İnsanlar & $\begin{array}{l}4500 \text { yı önce develerin Afrika'ya getirilmesi, o sırada meydana gelen iklim değişiklikleri ile ata vi- } \\
\text { rusun evrimini tetiklemiş olabileceği düşünülür ve deveye rastlamadan önce esas olarak kemirgen } \\
\text { popülasyonlarına yayıldığı varsayılır. Poxvirusların evrimlerinin ana mekanizmaları rastgele mutas- } \\
\text { yonların birikmesi ve bunların genomda sabitlenmesi, gen azalması ve rekombinasyonudur. Vac- } \\
\text { cinia virus hücresinin insan hücrelerinde etkili bir şekilde çoğaltılmasına izin veren O1L geninin } \\
\text { mutasyonun ana noktası olduğu düşünülmektedir. O1L geni, VARV'nin insanlara adaptasyonun- } \\
\text { daki önemli rolünü üstlenir (42). }\end{array}$ \\
\hline
\end{tabular}




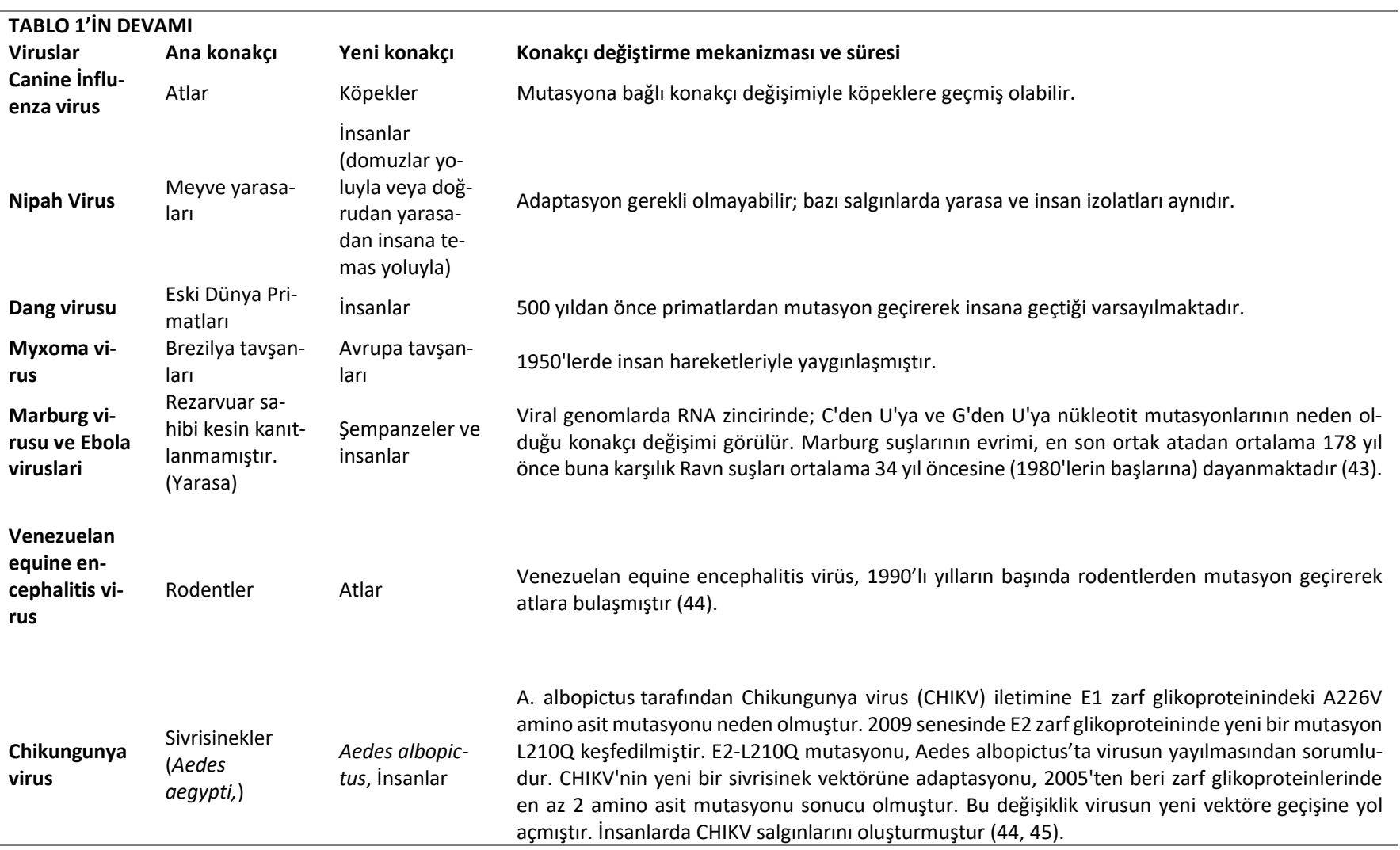

Son konakçı ve ara konakçılar arasındaki temas, virus transferi için ilk aşamadır. Bu nedenle virusun konakçı türü değişimi son konakçı ve ara konakçıların coğrafi, ekolojik ve davranışsal durumlarından etkilenir. Konakçı türlerin coğrafi dağılımını etkileyen faktörler, örneğin yaban hayatı ticareti, virusun konakçı değişiminin ortaya çıkmasını arttıran durumlardır. Insan kaynaklı değişiklikler, insan popülasyonunun genişlemesi ile insan davranışlarında değişiklikler dahil olmak üzere konakçı geçişini teşvik edebilir ya da çevrede olan değişiklikler; örneğin orman alanlarının azalmasına bağlı vahşi hayvanların şehirlere inmesi ve tarımsal genişlemeye bağlı virus konakçı değişiklikleri gözlenebilir (10). Zoonotik hastalık insidansını etkileyen faktörleri analiz etmek ve zoonotik hastalığın ortaya çıkma riskinin küresel dağılımını tahmin etmek için çeşitli yaklaşımlar kullanılmıştır (5). Ara konakçılar, normal olarak alternatif konakçılarla çok az teması olan hayvan viruslarını, alıcı konakçılarla yakın temasa sokarak hastalıkların ortaya çıkmasında önemli bir rol oynar (11). Örneğin; Severe Acute Respiratory Syndrom Corona virusunun (SARSCoV), önce yarasalarda ortaya çıktığı ve daha sonra misk kedileri (Saguma larvata) ve diğer çiftlik hayvanları ile insanlara geçerek enfekte ettiği görülmektedir. Kuş gribi etkeni olarak bilinen H5N1 influenza virusları ile insan enfeksiyonu çoğunlukla kümes hayvanlarının, çiftliklerde veya canlı kuş pazarlarında enfeksiyonundan sonra ortaya çıkar ve yabani kuş viruslarının insan popülasyonlarına erişmesine yol açar (9). Mutasyona bağlı konakçı değişimi göstermiş önemli enfeksiyon ajanı viruslar şunlardır;

\section{Severe Acute Respiratory Syndrome (SARS-CoV/SARS- CoV-2)}

Coronaviridae ailesinde yer alan viruslar zarflıdır ve 60-220 $\mathrm{nm}$ boyutunda tek zincirli RNA genomuna sahiptirler (13). 'Corona' ismi zarf üzerinde bulunan peplomerlerin taça benzetilmesinden dolayı verilmiştir. Coronavirus (CoV) enfeksiyonları insanların, hayvanların, kuşların, yarasaların, farelerin ve diğer birçok vahşi hayvanın solunum, gastrointestinal, karaciğer ve merkezi sinir sistemlerini etkiler (14). Örneğin, 2002'de Şiddetli akut solunum sendromu (Severe Acute Respiratory Syndrome-SARS) ve 2012'de Ortadoğu solunum sendromu (Middle East Respiratory Syndrome-MERS), hayvanlardan insanlara geçen zoonoz karakterli Coronavirus enfeksiyonlarıdır. Açıklanamayan bir pnömoni kaynağı olarak ilk kez Aralık 2019'da Wuhan'da ortaya çıkan ve yeni bir CoV olan SARS-CoV-2, hastaların solunum epitelinden izole edilmiştir. CoV içinde tanımlanan bir virustur.

2003-2004 yıllarında SARS-CoV insanlarda anjiyotensin dönüştürücü enzim 2 reseptörüne (ACE-2) bağlanmak için mutasyonlar geçirmiştir bunun sonucunda virus yarasalardan insanlara geçerek konakçı değişimi gerçekleşmiştir. MERS-CoV de mutasyonlara bağlı olarak develerden insanlara geçerek konakçı değişimi gerçekleştirmiştir. MERS-CoV çıkıntısal taç glikoproteini (S) ile, hücresel reseptör dipeptidil peptidaz 4'ü (DPP4) hedefler. Dizi karşılaştırması sonucunda bu etkileşime aracılık eden bir reseptör bağlanma alanı (RBD) ortaya çıkarmıştır (15). DPP4'e viral bağlanma ve hedef hücreye giriş için kritik olan birkaç önemli nokta tanımlanmıştır. Buradaki mutasyonel değişimler virusun yayılımını etkilemiştir (16). SARS-CoV-2 izolatlarında yapısal olmayan protein 6'yı (NSP6) ve ORF 10 bölgelerini etkileyen iki mutasyonun varlığı 
bulunmuştur ve bu konuyla ilgili çalışmalar devam etmekte$\operatorname{dir}(17)$. Ayrıca çalışmalar gelecekte bir SARS salgınının tekrarlayabileceğini ve farklı rezervuar konaklardan kaynaklanan SARS benzeri coronavirusların farklı bölgelerde salgınlara yol açabileceğini belirtmiştir. Yarasalardaki çeşitli SARS benzeri CoV'lerin keşfi bunu desteklemektedir ve konaklar arası geçişlerin mekanizmasını anlamanın faydalı olacağı belirtilmiştir (14).

\section{Human immunodeficiency virus (HIV)}

Human immunodeficiency virus (HIV), Retroviridae ailesi, Orthoretrovirinae alt ailesi içerisindeki Lentivirus genusunda yer almaktadır. HIV, insanlarda immün yetmezlik sendromuna (Acquired Immunodeficiency Syndrome-AIDS) neden olur. HIV, ilk ortaya çıktığı yıllarda insan popülasyonlarında hızlı bir şekilde yayılmış ve salgına neden olmuştur (18).

HIV, Simian İmmunodeficiency Virus (SIV)' dan 1930'lu yılardan sonra zaman içinde meydana gelen mutasyonlar sonucunda primatlardan insanlara geçerek konakçı değişimi meydana geldiği bildirilmiştir (19). HIV doğada en hızlı evrimleşen viruslardan biri olarak kabul edilmektedir. Bu durumdan reverz transkriptaz enzimindeki yüksek hata oranı, virusun yüksek çoğalma hızı ve viral varyantların seçimi etkilidir (20). Reverz transkriptazın RNA'dan DNA sentezlerken hata payı vardır. Reverz transkriptaz geninin de değişimiyle gen dizisinde mutasyonlar meydana gelir. Kemokin koreseptörleri; CCR5, makrofaj tropik, sinsityum oluşturmayan (R5) HIV'ın mukozal ve intravenöz bulaşında rol oynar (21). Kuzey Avrupa kökenli kişilerin \%13'üne yakın kısmında CCR5 genindeki (T hücresi üzerindeki HIV'in bağlandığı koreseptör) 32 baz çiftinde delesyon sonucu CCR5 reseptöründe mutasyon bulunmaktadır (22).

\section{Canine parvovirus (CPV)}

Parvoviridae ailesi içerisinde bulunan viruslar, tek iplikçikli DNA (single strand DNA-ssDNA) içeren, 18-26 nm büyüklügünde zarfsız viruslardır. 'Parvo' kelime anlamı olarak latince 'küçük' anlamına gelmektedir (23). Canine Parvovirus Tip 2 (CPV-2), köpeklerde morbidite ve mortalite oranı çok yüksek bir hastalığa neden olur. Etken çevre koşullarına oldukça dayanıklı olduğu için uzun süre bulaşma söz konusudur (24).

CPV-2, Feline Panleukopenia virusundan (FPLV) ya da Feline Parvovirus (FPV) alt türlerinden mutasyona uğrayarak konakçı değiştirmiş ve köpeklerde de görülmeye başlamıştır $(24,25)$. CPV-2 ortaya çıktığından beri FPLV ye göre çok hızlı gelişmiştir bunun sebebi yüksek mutasyon oranı ve kapsid genindeki (VP2) mutasyonlar evrimini hızlandırmıştır (25). FPV, köpek transferrin reseptörüne etkili bir şekilde bağlanmasına izin veren, kapsiddeki en az iki nokta mutasyonu sonucu 1970'lerin başında ortaya çıkıp, 1978'de dünyaya yayılmıştır (26). Bunun yanı sıra FPV virusundan CPV oluşumunda genetik rekombinasyonun etkili olduğu konusunda araştırmalar ortaya konulmuştur. Ülkemizde de canine ve feline parvovirusların mutasyonları ve konakçı değişime üzere çeşitli çalışmalar yapılmıştır $(27,28,29)$. CPV kaynaklı NS1 geninden ve FPLV kaynaklı VP1 geninden genomunun oluştuğu ve farklı FPV alt türleri arasındaki rekombinasyonun ilk belirtisi olduğu belirlenmiştir (30). FPV ve CPV-2 arasında en az altı ya da yedi amino asit (aa) değişikliği gözlenmektedir. Genellikle konakçı hücre transferrin reseptörü (TfR) ile etkileşen VP2 alanında mutasyonlar birikim göstermektedir (31).

\section{4. İnfluenza virus}

Influenza virusları, Orthomyxoviridae ailesinde bulunan tek zincirli RNA viruslarıdır (32). İnfluenza virus genomlarında antijenik değişimler mevcuttur. Büyük değişimler (antijenik shift) rekombinasyonlardan köken alır. Küçük değişimler (antijenik drift) mutasyonlardan köken alır (33). Virusun hemaglütinin ve nöyraminidaz genleri mutasyona çok açık bölgelerdir ve bu proteinler üzerinde oluşan antijenik değişimler patogenez ve epidemiyoloji açısından oldukça etkilidir (33). Genetik değişiklikler yeni İnfluenza virusu suşlarının ortaya çıkmasının nedenidir. Antijenik sürüklenme (drift) ve kayma (shift), nokta mutasyonları ve virusların genomları arasında genetik materyalin yeniden sıralanmasını içeren modifikasyonlarla ilişkilidir (7). İnfluenza virusları çok sayıda konağı enfekte eder ve konakçı etkileşimi ile yüksek mutasyon dinamiği gösterir. İnfluenza popülasyonlarının yeni konakçılara uyum sağlama ve bağışıklık sisteminden kaçma kabiliyeti yüksektir. Mutasyonlar genellikle zararlıdır, bu da viral adaptasyona bir engel oluşturur. Ayrıca, mutasyonların nasıl gerçekleştiğinin bilinmesi viral evrimi tahmin etmede ve daha iyi aşılar, antiviraller üretmede önemlidir (34). Antijenik driftler yeni varyantların ana nedenidir ve yıllık grip salgınlarına neden olur. Her ne kadar bu değişiklikler pandemiye yol açmasa da belirli bir süre boyunca antijenik sürüklenme, orijinal pandemik virustan önemli ölçüde farklı bir suş oluşturabilir (35). Kuş gribi virusu konakçı aralığının insanlara değişmesinde önemli bir belirleyici olan; PB2 polimeraz proteinindeki E627K mutasyonudur (36). Ek olarak, 1918 influenza pandemisine neden olan $\mathrm{H} 1 \mathrm{~N} 1$ alt tipi virusun yanı sıra 1997 'de Hong Kong'da tanımlanan H5N1 kuş gribi virusunun her ikisi de oldukça patojenik İnfluenza viruslarıdır ve PB1F2'de N66S mutasyonu içerir. Bu mutasyonun, bu virusların viral patojenitesini önemli ölçüde artırdığı öne sürülmüştür (37).

\section{Kızamık virusu (Measles virus / MV)}

Kızamık virusu, Paramyxoviridae ailesinin Paramyxovirinae alt ailesinin Morbillivirus cinsinde yer alır (38). Kızamık virusu (MV), tek zincirli, segmentsiz negatif polariteli RNA genomuna sahip zarflı bir virustur ve insan olmayan primatlarda (Non-Human Primates-NHP'ler) ve insanlarda hastalığa neden olur (39).

Sığırlarda hastalık oluşturan sığır vebası virus (Rinderpest-RPV) ile kızamık virusu (Measles Virus-MV) yakınlık gösterdiği için sığır ve insanların etkileşime geçtiği yıllarda zoonotik bir enfeksiyon olarak kabul edilmiştir. MV, Morbillivirus cinsinin bir üyesidir ve bu grup içerisinde $M V$, Peste des petits ruminants virus (PPRV), Canine distemper virus (CDV), Phocine distemper virus (PDV) ve RPV ile birlikte bulunur. Ancak genetik ve antijenik olarak en çok sığırların bir patojeni olan RPV ile yakın ilişkilidir. MV'nin, sığırların ve insanların yakın bir yerde yaşadığı bir ortamda geliştiği düşünülmektedir (40). Kızamık virusu , o zamanlar yaygın olan sığır vebası virusundan büyük olasılıkla 11 . ve 12 . yüzyıllar arasında 
ortaya çıkmıştır (40). MV'nin ortaya çıkmasının tarih öncesi çağda meydana geldiği düşünülmektedir (41). Kızamık virusunun insan dışı primat (NHP) bulaşmasının primat popülasyonlarında önemli morbidite ve mortaliteye neden olduğu gösterilmiştir (41).

\section{SONUÇ}

Bazı hastalıkların, insanlarda yok edildikten sonra hayvan konakçıları/rezervuarları aracılığıyla insanlarda tekrar görülebileceğini gösteren kanıtlar vardır (9). Ortaya çıkan bulaşıcı hastalıklar son yıllarda önemli morbidite ve mortaliteye sebep olmuştur. Birçok hastalığa hedef türe ait olmayan viruslar neden olmaktadır. Insan olmayan primatlardan HIV; yarasalardan SARS-CoV, SARS-CoV-2; domuzlardan pandemik influenza virus suşu (H1N1 çeşitli mutasyonlar sonucu konakçı değişimiyle insanda ortaya çıkarak bulaşıcı hastalıklara sebep olmuşlardır. Furuse ve ark. (40) çalışmalarında belirttiği üzere; ortaya çıkan bulaşıcı hastalıkların insan popülasyonuna girdikten sonra, evrimsel ve epidemiyolojik yönden araştırılması gelecekteki benzer durumlara karşı önemli bilgiler verecektir. Sonuç olarak; virusların zaman içerisindeki geçirdikleri mutasyonlarla birlikte konakçı değişimleri gerçekleşmiştir. Bu konakçı değişimine bağlı olarak yeni konakçılara adaptasyon ile beraber yeni tip viruslar oluşmuştur ve viral enfeksiyonlar meydana gelmiştir. Mutasyonel değişimler sonucu, son konakçının insan olmasıyla beraber zoonoz özellik kazanarak pandemik boyuta ulaşabilen salgınlar oluşturmaktadır. Vahşi veya evcil hayvanlarda binlerce virus arasında hangilerinin insanlarda ortaya çıkacağını veya bir sonraki ortaya çıkan zoonotik virusların nereden ve ne zaman çıkacağını belirlemek hala mümkün olmasa da, çalışmalar ortak yolları göstermekte ve önleyici stratejiler önermektedir. Tedavilerde oluşan direncin nasıl evrimleştiğini anlamak daha iyi tedaviler geliştirilmesine yardımcı olacaktır. Ayrıca vektör kontrolü virusların rezervuarlarından yeni konakçılara bulaşmasını sınırlayabilir. Yeni virusların kökenleri hakkında daha iyi bilgi ile doğal konakçılarında potansiyel olarak ortaya çıkan virusları tanımlamak ve kontrol etmek mümkün olabilir. Enfeksiyon kontrol prosedürleri, karantina uygulamaları, rezervuar ve alıcı konaklar arasındaki teması önemli ölçüde azaltabilir, salgınları önleyebilir veya konakçı transferinden sonra bunları sonlandırabilir. Ancak bu önlemler sınırlıdır. Bu yüzden, viruslar ve ortaya çıkarma potansiyeli olan salgınlar bir bütün olarak ele alınıp "Tek Sağlık, Tek Tıp ve Tek Viroloji" konseptinde çalışılmalı ve araştırılmalıdır.

\section{KAYNAKLAR}

1. Fenner F. (1999). Genetics of Animal Viruses. In: Encyclopedia of Virology. Granoff A, Webster RG (eds). pp. 606-613. Saunders Elsevier, Missouri, USA.

2. Fleischmann WR. (2011). Viral Genetics. In: Medical Microbiology. Baron S (ed). 4th ed. Chapter 43. The University of Texas Medical Branch at Galveston, Galveston, USA.

3. Drake JW, Holland JJ. (1999). Mutation Rates Among RNA Viruses. PNAS. 96(24):13910-13913.

4. Lauring AS, Frydman J, Andino R. (2013). The Role of Mutational Robustness in RNA Virus Evolution. Nat Rev Microbiol. 11(5):327-336.
5. Wohl S, Schaffner SF, Sabeti PC. (2016). Genomic Analysis of Viral Outbreaks. Annu Rev Virol. 3(1):173-195.

6. Algül Ö, Dar BPW, Öksüz Z. (2019). Antiviral İlaçlardaki Gelişmeler ve Değerlendirilmesi. MUTFTD. 9(2):160-170.

7. Yeşilbağ K. (2002). Mutasyonel Değişimler ve Veteriner Virolojideki Önemi. Uludağ Üniv Vet Fak Derg. 21:125-131.

8. Lehnert S. (2007). Biomolecular Action of Ionizing Radiation. Boca Raton, FL: CRC Press.

9. Parrish CR, Holmes EC, Morens DM, Park EC. (2008). Cross-Species Virus Transmission and the Emergence of New Epidemic Diseases. Microbiol Mol Biol Rev. 72(3):457-470.

10. Geoghegan JL, Duchêne S, Holmes EC. (2017). Comparative Analysis Estimates the Relative Frequencies of Co-divergence and Cross-species Transmission within Viral Families. PLoS Pathog. 13(2):1006215.

11. Petrova VN, Russell CA. (2018). The Evolution of Seasonal Influenza Viruses. Nat Rev Microbiol. 16(1):47-60.

12. Huelsenbeck JP, Bull JJ, Clifford CW. (1996). Cunningham. Combining Data in Phylogenetic Analysis. Trends Ecol Evol. 11. 4:152-158.

13. Oshiro LS, Schieble JH, Lennette EH. (1971) Electron Microscopic Studies of Coronavirus. J Gen Virol. 12(2):161-168.

14. Kırdar S, Koç BT. (2020). SARS-CoV2 Virüsünün Potansiyel Rezervuarları ve Yarasalarla Bulaşabilecek Diğer Zoonotik Virüsler. J BSHR. 4(2):89-97.

15. Shereen MA, Khan S, Kazmi A, Bashir N, Siddique R. (2020). COVID-19 Infection: Origin, Transmission, and Characteristics of Human Coronaviruses. J Adv Res. 24:91-98.

16. Wang N, Shi X, Jiang L, et al. (2013). Structure of MERS-CoV Spike Receptor-binding Domain Complexed with Human Receptor DPP4. Cell Res. 23(8):986-993.

17. Benvenuto D, Angeletti S, Giovanetti M, et al. (2020). Evolutionary Analysis of SARS-CoV-2: How Mutation of Non-Structural Protein 6 (NSP6) Could Affect Viral Autophagy. J Infect. 81(1):e24-27.

18. Yıldırmak T. (2017). HIV Biyolojisi ve Patogenezi. Sağlık Bilimleri Üniversitesi (SBÜ). Erişim: https://docplayer.biz.tr/52434203Hiv-biyolojisi-ve-patogenezi-doc-dr-taner-yildirmak-sbu-okmeydani-saum-24-mart-2017-cuma.html Erişim tarihi: 17.04.2020.

19. Blood, German Advisory Committee. (2016). Human Immunodeficiency Virus (HIV). Transfus Med Hemother. 43(3):203.

20. Memişoğlu AS. (2014). Evrimsel Düşünce İçin Bir Örnek -HIV. Erişim: http://kisi.deu.edu.tr//asli.memisoglu/Evrim/1-Evrimsel\%20d\%c3\%bc\%c5\%9f\%c3\%bcnce\%20i\%c3\%a7in\%20bir\%20 \%c3\%b6rnek-HIV.pdf Erişim tarihi: 27.05.2020.

21. Blanpain C, Libert F, Vassart G, Parmentier M. (2002). CCR5 and HIV Infection. Recept Channels. 8(1):19-31.

22. Kutlu SS. (2017). HIV Patogenez, Klinik ve İmmunolojik Sınıflama. Erişim: https://www.klimik.org.tr/wp-content/uploads/2017/12/HIV-Patogenez-Klinik-ve-\%C4\%BOmmunolojikS\%C4\%B1n\%C4\%B1flama-Selda-SAYIN-KUTLU.pdf Erişim Tarihi: 20.04.2020.

23. Kelly WR. (1978). An Enteric Disease of Dogs Resembling Feline Panleucopaenia. Aust Vet J. 54(12):593-593.

24. Zhou P, Zeng W, Zhang X, Li S. (2017). The Genetic Evolution of Canine Parvovirus - A new Perspective. PLoS One. 12(3):e0175035.

25. Battilani M, Scagliarini A, Ciulli S, Morganti L, Prosperi S. (2006). High Genetic Diversity of the VP2 Gene of a Canine Parvovirus Strain Detected in a Domestic Cat. Virology. 352(1):22-6. 
26. Decaro N, Desario C, Addie DD, et al. (2007). The Study Molecular Epidemiology of Canine Parvovirus, Europe. Emerg Infect Dis. 13(8):1222-4.

27. Koç BT, Oğuzoğlu TÇ. (2016). The Investigation of Feline Parvoviruses (FPVs) into Two Different Phylogenetic Lineages in Turkey. JABS. 10(2): 04-07.

28. Akkutay-Yoldar Z, Koç BT. (2020). Phylogenetic Analysis of Canine Parvoviruses from Turkey. Med Weter. 76(01):6334-2020.

29. Akkutay-Yoldar Z, Koç BT. (2019). Comparison of Partial and Full VP2 Gene Sequences of Parvovirus from Domestic Cats in Turkey. Vet Méx. OA. 6(4): 1-12.

30. Ohshima T, Mochizuki M. (2009). Evidence for Recombination Between Feline Panleukopenia Virus and Canine Parvovirus Type 2. J Vet Med Sci. 71(4):403-8.

31. Decaro N, Buonavoglia C. (2012). Canine Parvovirus-a Review of Epidemiological and Diagnostic Aspects, with Emphasis on Type 2c. Vet Microbiol. 155(1):1-12.

32. Capua I, Alexander DJ. (2009). Ecology, Epidemiology and Human Health Implications of Avian Influenza Virus Infections. In: Avian Influenza and Newcastle Disease. Capua I, Alexander DJ. (eds). pp. 1-18. Springer Milan, Italy.

33. Durviaux S, Treanor J, Beran J, et al. (2014). Genetic and Antigenic Typing of Seasonal Influenza Virus Breakthrough Cases from a 2008-2009 Vaccine Efficacy Trial. Clin Vaccine Immunol. 21(3):271-9.

34. Lyons DM, Lauring AS. (2018). Mutation and Epistasis in Influenza virus Evolution. Viruses. 10(8):3390 10080407.

35. Carrat F, Flahault A. (2007). Influenza vaccine: The Challenge of Antigenic Drift. Vaccine. 25(39-40):6852-62.

36. Arai Y, Kawashita N, Daidoji T, et al. (2016). Novel Polymerase Gene Mutations for Human Adaptation in Clinical Isolates of Avian H5N1 Influenza Viruses. PLoS Pathog. 12(4):e1005583.
37. Shao W, Li X, Goraya MU, Wang S, Chen J-L. (2017). Evolution of Influenza A Virus by Mutation and Re-assortment. Int J Mol Sci. 18(8).

38. Vries RD, Duprex WP, Swart RL. (2015). Morbillivirus Infections: An Introduction. Viruses. 7(2):699-706.

39. Laksono B, de Vries R, McQuaid S, Duprex W, de Swart R. (2016). Measles Virus Host Invasion and Pathogenesis. Viruses. $8(8): 210$

40. Furuse Y, Suzuki A, Oshitani H. (2010). Origin of Measles Virus: Divergence from Rinderpest Virus Between the 11th and 12th Centuries. Virol J. 7(1):52.

41. Jones Engel, Schillaci MA, Lee B, et al. (2006). Considering Human-primate Transmission of Measles Virus Through the Prism of Risk Analysis. Am J Primatol. 68(9):868-879.

42. Babkin IV, Babkina IN. (2015). The Origin of the Variola Virus. Viruses. 7(3):1100-1112.

43. Khrustalev VV, Barkovsky EV, Khrustaleva TA. (2015). Local Mutational Pressures in Genomes of Zaire Ebola Virus and Marburg Virus. Adv Bioinformatics. 2015:678587.

44. Longdon B, Brockhurst MA, Russell CA, Welch JJ, Jiggins FM (2014). The Evolution and Genetics of Virus Host Shifts. PLoS Pathog 10 (11): e1004395.

45. Tsetsarkin KA, Weaver SC (2011). Sequential Adaptive Mutations Enhance Efficient Vector Switching by Chikungunya Virus and Its Epidemic Emergence. PLoS Pathog 7(12): e1002412.

Sorumlu Yazar:
Selin Nur KIZILKOCA
Aydın Adnan Menderes Üniversitesi
Veteriner Fakültesi Viroloji Anabilim Dalı, Efeler/Aydın,
TÜRKiYE
E-posta: selinkizilkoca@hotmail.com

